\title{
A Spectrophotometric Flow Injection Method for Determination of Ultratrace Amounts of Phenylhydrazine by Its Inhibition Effect on the Reaction of Thionin and Nitrite
}

\author{
M. Keyvanfard and Kh. Alizad \\ Department of Chemistry, Majlesi Branch, Islamic Azad University, Isfahan 8631656451, Iran \\ Correspondence should be addressed to M. Keyvanfard; keyvan45638@yahoo.com
}

Received 7 May 2012; Revised 23 June 2012; Accepted 25 June 2012

Academic Editor: Antonio Romerosa

Copyright (c) 2013 M. Keyvanfard and Kh. Alizad. This is an open access article distributed under the Creative Commons Attribution License, which permits unrestricted use, distribution, and reproduction in any medium, provided the original work is properly cited.

\begin{abstract}
A simple flow injection colorimetric procedure for determining phenylhydrazine was established. It is based on the reaction of phenylhydrazine in sulfuric acid with thionin and sodium nitrite. Reaction was monitored spectrophotometrically by measuring thionin absorbance at $\lambda_{\max }=602 \mathrm{~nm}$. A standard or sample solution was injected into the sulfuric acid stream, which was then merged with sodium nitrite stream and thionin stream. Optimum conditions for determining phenylhydrazine were investigated by univariate method. Under the optimum conditions, a linear calibration graph was obtained over the range $0.05-0.60 \mu \mathrm{mol} \mathrm{L} \mathrm{L}^{-1}$, and the detection limit was $0.027 \mu \mathrm{mol} \mathrm{L}^{-1}(s / n=3)$. The proposed method has been satisfactorily applied to the determination of phenylhydrazine in human serum and water samples.
\end{abstract}

\section{Introduction}

Phenylhydrazine has many side effects. Its absorption through skin causes erosion, burns, and contact dermatitis and if exposures be in toxic dosage, skin contact can produce symptoms in other organ systems. Its inhalation in the form of combustible solid, liquid, and vapor produces cough and dyspnea. Its swallowing causes vomiting, faint, jaundice, and dizziness. Phenylhydrazine too can breakdown red blood cells (RBCs) and produce hemolytic anemia and consequential involvement of other tissues, such as spleen, liver, and kidney injury. Chronic exposure causes adverse effects in Bone Marrow (BM), liver, kidney, and it also increases the cancer risk [1].

Several methods have been reported for the determination of phenylhydrazine. These include spectrophotometry [2-5], chromatography [6], H-point standard addition method [7, 8], kinetic methods [9-12], and electrochemical methods [13-16]. According to our best knowledge, this is the first flow injection (FI) method proposed for the determination of phenylhydrazine. This proposed method does not require a solvent extraction step; hence, the use of organic solvent is avoided.

This paper studies a rapid, sensitive, and cost-effective flow injection method for the determination of phenylhydrazine based on the spectrophotometric detection by the reaction of phenylhydrazine standard in sulfuric acid, thionin, and sodium nitrite as a sensitizer. Thionin and phenylhydrazine have the following structure (Figure 1). Measurements were made at $602 \mathrm{~nm}$.

\section{Experimental}

2.1. Apparatus. The 8-channel peristaltic pump (ismatec, MCP process, IP 65,) was fitted for pumping solutions. Silicon rubber tube with $0.8 \mathrm{~mm}$ i.d. was used for delivery of the solutions. A mixed solution of thionin, nitrite, and sulfuric acid as a carrier stream was delivered through silicon rubber tubing $\left(\right.$ at $\left.35^{\circ} \mathrm{C}\right)$. The thermostatic water bath (Gallen Kamp Griffin, BGL 240 V) was used at a given temperature of $35 \pm 0.1^{\circ} \mathrm{C}$. The standard solution of phenylhydrazine 
<smiles>CC(=O)[O-]</smiles>

(a)

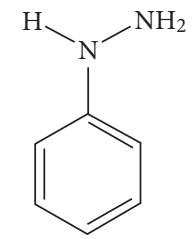

(b)
FIGURE 1: Structure of (a) thionin and (b) phenylhydrazine.

was injected into a carrier stream with a sample injector (Rhedyne, model 9125). An UV-Visible spectrophotometer (2501 CECIL) equipped with a flow-through cell with $10 \mathrm{~mm}$ path length connected a recorder was used for monitoring the variation in the absorbance spectrum.

2.2. Reagents and Solutions. All chemicals were of analytical reagent grade and were used without further purifications. A $1.0 \times 10^{-3} \mathrm{~mol} \mathrm{~L}^{-1}$ stock standard solution of phenylhydrazine was prepared by dissolving $0.0147 \mathrm{~g}$ of phenylhydrazinine chloride (Merck, $\mathrm{M}=144.6 \mathrm{~g} / \mathrm{mol}$ ) in distilled water and diluting it to $100 \mathrm{~mL}$. Solutions of the desired concentrations were obtained by diluting the stock solution to volume with distilled deionize water. A $100 \mathrm{~mL}$ of 2.0 $\times 10^{-3} \mathrm{~mol} \mathrm{~L}^{-1}$ sodium nitrite solution was prepared by dissolving $0.0138 \mathrm{~g}$ of $\mathrm{NaNO}_{2}$ (Merck, $\mathrm{M}=69.0 \mathrm{~g} / \mathrm{mol}$ ) in distilled water and diluting it to mark in a $100 \mathrm{~mL}$ volumetric flask. A $4.0 \times 10^{-4} \mathrm{~mol} \mathrm{~L}^{-1}$ thionin solution was directly prepared by dissolving $0.0115 \mathrm{~g}$ of thionin (Merck, $\mathrm{M}=$ $287.34 \mathrm{~g} / \mathrm{mol}$ ) in distilled water and diluting it to mark in a $100 \mathrm{~mL}$ volumetric flask. Sulfuric acid solution $\left(2.0 \mathrm{~mol} \mathrm{~L}^{-1}\right)$ was prepared by diluting a known volume of its concentrated solution (Merck). All laboratory glasswares were cleaned by soaking in a detergent solution and acidified solution, followed by washing with concentrated nitric acid and rinsing several times with distilled deionize water.

2.3. Recommended Procedure. Using of this the three channels manifold as shown in Figure 2, a $200 \mu \mathrm{L}$ sample or standard solution containing phenylhydrazine was injected into the reagent stream consisting of $2.0 \mathrm{~mol} \mathrm{~L}^{-1}$ of sulfuric acid and $0.9 \times 10^{-4} \mathrm{~mol} \mathrm{~L}^{-1}$ of sodium nitrite, which were then merged with $2.5 \times 10^{-4} \mathrm{~mol} \mathrm{~L}^{-1}$ thionin at the same optimum flow rate of $0.3 \mathrm{~mL} \mathrm{~min}{ }^{-1}$. Subsequently, the sample zone flowed through the mixing coils no. 1 and 2 with 75 and $125 \mathrm{~cm}$ in reaction coil length, respectively, where the reagents to be mixed and flowed through the detection unit. The signal was monitored by the spectrophotometric detector at $602 \mathrm{~nm}$, and the FI signal was recorded on a chart recorder.

2.4. Sample Preparation. Mineralization of $2.0 \mathrm{~mL}$ of the human serum was carried out for $1.0 \mathrm{~h}$ at $100^{\circ} \mathrm{C}$ with the addition of $4 \mathrm{~mL}$ of concentrated nitric acid [17]. Then

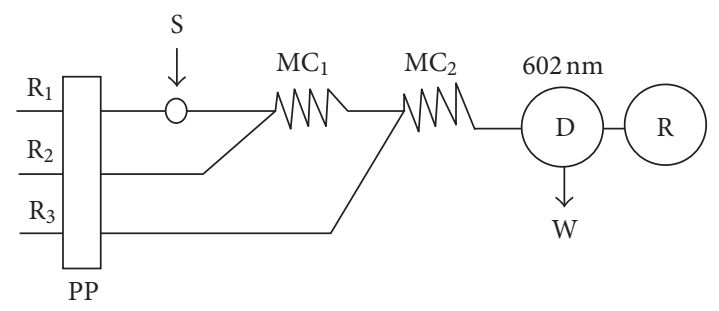

FIgURE 2: Proposed FI manifolds: $\mathrm{R}_{1}$, sulfuric acid; $\mathrm{R}_{2}$, sodium nitrite; $\mathrm{R}_{3}$, thionin; $\mathrm{PP}$, peristaltic pump; $\mathrm{MC}_{1}$, mixing coil no. 1 ; $\mathrm{MC}_{2}$, mixing coil no. 2; $\mathrm{D}$, detector; $\mathrm{R}$, recorder; $\mathrm{W}$, waste.

samples were analyzed directly after neutralization with sodium hydroxide solution and dilution with doubly distilled water to a suitable volume.

The water samples were collected in $1.0 \mathrm{~L}$ polyethylene bottles from Zayandeh Rood River, Isfahan province and analyzed immediately after sample digestion. The water samples were filtered through Whatman no. 41 filter paper, then $5 \mathrm{~mL}$ of each filtered water sample was accurately transferred into a $25 \mathrm{~mL}$ round bottom flask and made up to the mark with distilled deionize water, mixed, subsequently analyzed by the proposed FI method.

\section{Results and Discussion}

The proposed flow system was undertaken for the development of FI procedure for analysis of phenylhydrazine based on the phenylhydrazine with thionin in sulfuric acid and sodium nitrite resulting in having an absorption maximum at $602 \mathrm{~nm}$. The present work was developed and optimized by an univariate method. The variable by variable methods was applied to select the appropriate conditions for the flow injection spectrophotometric determination of phenylhydrazine. To have more signals, the effect of reagent concentrations and manifold variables on the analytical signal was studied.

3.1. Choice of FI Manifold. Preliminary investigation has been carried out to obtain the most suitable FI manifold for phenylhydrazine thionin in a sodium nitrite/sulfuric acid. Three FI manifold have been designed namely a threechannel FI manifold two channels designed FI various and a single-channel FI manifold.

They were tested for determining phenylhydrazine in standard solutions. It was preferable to use the three-channel FI manifold for phenylhydrazine determination since it provided a greatest sensitivity, reproducibility, and relative high sample throughput.

3.2. Effect of Sulfuric Acid, Thionin, and Sodium Nitrite Concentration. The effect of varying concentration of $\mathrm{H}_{2} \mathrm{SO}_{4}$ solutions between $0.2-5.0 \mathrm{~mol} \mathrm{~L}^{-1}$ was examined. The highest peak height was recorded when the concentration $\mathrm{H}_{2} \mathrm{SO}_{4}$ solution was $2.0 \mathrm{~mol} \mathrm{~L}^{-1}$ and was therefore chosen as optimum concentration. Further increasing of the sulfuric acid 


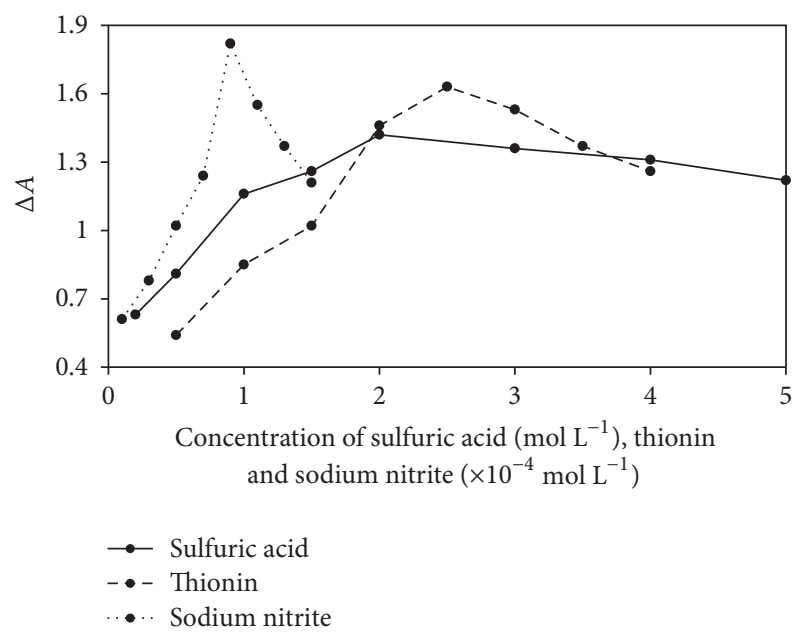

FIGURE 3: Effect of sulfuric acid, thionin, and sodium nitrite concentrations on the mean of peak height $(n=5)$ of $0.1 \mu \mathrm{mol} \mathrm{L}-1$ phenylhydrazine standard solution.

concentration makes the peak height decreased gradually up to $5.0 \mathrm{~mol} \mathrm{~L}^{-1}$ (Figure 3).

The concentration of thionin solution was optimized. Various concentrations over the range $0.5 \times 10^{-4}-4.0 \times$ $10^{-4} \mathrm{~mol} \mathrm{~L}^{-1}$ were investigated. It was found that the peak height increased with increasing thionin concentration and reached a maximum peak height at $2.5 \times 10^{-4} \mathrm{~mol} \mathrm{~L}^{-1}$, above which the peak height decreased. Thus, $2.5 \times 10^{-4} \mathrm{~mol} \mathrm{~L}^{-1}$ of thionin was used subsequently (Figure 3 ).

The effect of various concentrations of sodium nitrite solution $\left(0.1 \times 10^{-4}-1.5 \times 10^{-4} \mathrm{~mol} \mathrm{~L}^{-1}\right)$, on the absorption of the sodium nitrite (as peak height) was examined. The sodium nitrite concentration which exhibited the greatest peak height was found to be $0.9 \times 10^{-4} \mathrm{~mol} \mathrm{~L}^{-1}$ and was therefore chosen as optimum concentration. Further increasing of the sodium nitrite concentration makes the peak height decreased gradually up to $1.5 \times 10^{-4} \mathrm{~mol} \mathrm{~L}^{-1}$ (Figure 3).

3.3. Effect of Mixing Coil Length, Injection Loop Volume, and Flow Rate. These studies were carried out at various mixing coil lengths between 50 and $275 \mathrm{~cm}$ for mixing coil $1\left(\mathrm{H}_{2} \mathrm{SO}_{4}\right.$, sodium nitrite) and mixing coil $2\left(\mathrm{H}_{2} \mathrm{SO}_{4}\right.$, sodium nitrite, thionin), injection loop volumes between 50 and $400 \mu \mathrm{L}$ were investigated. It was found that the peak height increased with the mixing coil 1 and mixing coil 2 lengths up to 75 and $125 \mathrm{~cm}$, respectively. Both mixing coil lengths of $50,75,125$, 175,225 , and $275 \mathrm{~cm}$ provided the peak height $(\Delta A)$ of 1.35 , $1.90,1.81,1.76,1.74,1.70$ and $1.42,1.69,2.09,1.88,1.86$, 1.81 , respectively. The optimum mixing coil lengths of no. 1 and no. 2 for subsequence studied were 75 and $125 \mathrm{~cm}$, respectively.

The influence of the sample/standard volume on the absorbance was recorded by injecting volumes in the range 50 and $400 \mu \mathrm{L}$ of phenylhydrazine standard solution $\left(0.1 \mu \mathrm{mol} \mathrm{L}{ }^{-1}\right)$. It was shown that the peak height $(\Delta A)$ increased from 1.51 to 2.33 on increasing the injection volume from 50 to $400 \mu \mathrm{L}$. It was found that the peak height increased with the injection volumes up to $200 \mu \mathrm{L}$, and the injection volume of $50,100,200,250,300$, and $400 \mu \mathrm{L}$ produced the peak height $(\Delta A)$ of $1.51,1.92,2.87,2.32$, 2.29 , and 2.25 , respectively. The appropriate peak height was reached at $200 \mu \mathrm{L}$. The most suitable injection loop volume value for further use was $200 \mu \mathrm{L}$.

The effects of sulfuric acid, thionin, and sodium nitrite solutions flow rates were investigated on the determination of phenylhydrazine standard solution $\left(0.1 \mu \mathrm{mol} \mathrm{L}{ }^{-1}\right)$. The peak heights were monitored from the flow rate of $0.2-0.6 \mathrm{~mL} \mathrm{~min}^{-1}$ for all solution streams. The peak height increased with increasing flow rate of each stream up to $0.3 \mathrm{~mL} \mathrm{~min}^{-1}$ for sulfuric acid and sodium nitrite solutions, which were then merged with the flowing stream of thionin solution with the flow rate of $0.3 \mathrm{~mL} \mathrm{~min}^{-1}$ above which the peak height slightly decreased. Thus, $0.3 \mathrm{~mL} \mathrm{~min}^{-1}$ of sulfuric acid, thionin, and sodium nitrite solutions was regarded as the optimum flow rates.

3.4. Analytical Characteristics. Analytical characteristics for the determination of phenylhydrazine were studied under the optimum conditions (Table 1).

3.5. Calibration Curve. Using this the proposed FI manifold for the determination of phenylhydrazine under the optimum conditions, the linear calibration graph over the range of $0.05-0.6 \mu \mathrm{mol} \mathrm{L}^{-1}$ of phenylhydrazine standard solution was established, which could be expressed by the regression equation $y=1.0929 x+3.0029\left(r^{2}=0.9990\right)$ where $y$ represents the peak height $(\Delta A)$ and $x$ was phenylhydrazine concentration in $\mu \mathrm{mol} \mathrm{L}^{-1}$ after subtraction of blank. Thus, the amounts of phenylhydrazine in samples can be quantified according to the above regression lines of equation. The detection limit was defined as the concentration of analyte that gives the signal that is different from the blank by an amount equal to three times the standard deviation of the blank signal $(s / n=3)$. It was found to be $0.027 \mu \mathrm{mol} \mathrm{L}^{-1}$. The quantitation limit (defined as ten time standard deviation) was studied and found to be $0.091 \mu \mathrm{mol} \mathrm{L}^{-1}$. It is shown that the present method was very suitable for determining relatively large amounts of phenylhydrazine in human serum and Zayandeh Rood water.

3.6. Reproducibility and Accuracy. The relative standard deviation of the proposed method (peak height $(\Delta A)$ ) calculated from 5 replicate injections of 0.2 and $0.4 \mu \mathrm{mol} \mathrm{L}^{-1}$ of phenylhydrazine was $0.62 \%$ and $0.56 \%$, respectively. The recoveries were determined with the standard addition method, in which phenylhydrazine $\left(0,0.1,0.2,0.4\right.$, and $\left.0.5 \mu \mathrm{mol} \mathrm{L}^{-1}\right)$ was added and mixed with human serum and Zayandeh Rood water samples the human serum and water samples were analyzed using the proposed method. The percentage recoveries of $0.1,0.2,0.4$, and $0.5 \mu \mathrm{mol} \mathrm{L}^{-1}(n=5)$ of phenylhydrazine were found to be between $92.50 \%-108.00 \%$, showing that the proposed method could provide acceptable 
TABLE 1: Variable ranges study and optimum conditions for the determination of phenylhydrazine.

\begin{tabular}{lcc}
\hline Parameter studied & Range studied & Optimum level \\
\hline Wavelength $(\mathrm{nm})$ & $200-700$ & 602 \\
Sulfuric acid concentration $\left(\mathrm{mol} \mathrm{L}^{-1}\right)$ & $0.2,0.5,1.0,1.5,2.0,3.0,4.0,5.0$ & 2.0 \\
Thionin concentration $\left(\times 10^{-4} \mathrm{~mol} \mathrm{~L}^{-1}\right)$ & $0.5,1.0,1.5,2.0,2.5,3.0,3.5,4.0$ & 2.5 \\
Sodium nitrite concentration $\left(\times 10^{-4} \mathrm{~mol} \mathrm{~L}^{-1}\right)$ & $0.1,0.3,0.5,0.7,0.9,1.1,1.3,1.5$ & 0.9 \\
Flow rate $\left(\mathrm{mL} \mathrm{min}{ }^{-1}\right)$ & $0.2,0.3,0.4,0.5,0.6$ & 0.3 \\
Mixing coil $[\mathrm{I}](\mathrm{cm})\left[\right.$ phenylhydrazine $+\mathrm{H}_{2} \mathrm{SO}_{4}+$ sodium nitrite] & $50,75,125,175,225,275$ & 75 \\
Mixing coil $[\mathrm{II}](\mathrm{cm})\left[\right.$ phenylhydrazine $+\mathrm{H}_{2} \mathrm{SO}_{4}+$ sodium nitrite + thionin] & $50,75,125,175,225,275$ & 125 \\
Injection volume $(\mu \mathrm{L})$ & $50,100,200,250,300,400$ & 200 \\
\hline
\end{tabular}

TABLE 2: Determination of phenylhydrazine in real samples.

\begin{tabular}{|c|c|c|c|}
\hline Sample ${ }^{\mathrm{a}}$ & $\begin{array}{c}\text { Concentration of phenylhydrazine } \\
\text { added }\left(\mu \mathrm{mol} \mathrm{L}^{-1}\right)\end{array}$ & $\begin{array}{l}\text { Concentration of phenylhydrazine } \\
\left.\text { found }(\mu \mathrm{mol} \mathrm{L})^{-1}\right)\end{array}$ & Recovery \% \\
\hline \multirow{5}{*}{ Human serum } & 0.000 & - & - \\
\hline & 0.100 & $0.108 \pm 0.002$ & 108.00 \\
\hline & 0.200 & $0.185 \pm 0.003$ & 92.50 \\
\hline & 0.400 & $0.378 \pm 0.001$ & 94.50 \\
\hline & 0.500 & $0.527 \pm 0.004$ & 105.40 \\
\hline \multirow{5}{*}{ River water (Zayandeh Rood) } & 0.000 & - & - \\
\hline & 0.100 & $0.105 \pm 0.005$ & 105.00 \\
\hline & 0.200 & $0.193 \pm 0.002$ & 96.50 \\
\hline & 0.400 & $0.389 \pm 0.005$ & 97.25 \\
\hline & 0.500 & $0.521 \pm 0.007$ & 104.20 \\
\hline
\end{tabular}

${ }^{a}$ Average from five determinations.

TABLE 3: Effect of foreign ions on the determination of $8 \mathrm{nM}$ phenylhydrazine.

\begin{tabular}{|c|c|}
\hline Foreign species & $\begin{array}{c}\text { Tolerated ratio } \\
W_{\text {Species }} / W_{\text {Phenylhydrazine }} \\
\end{array}$ \\
\hline $\begin{array}{l}\mathrm{NO}_{3}{ }^{-}, \mathrm{SO}_{3}{ }^{2-}, \mathrm{Cl}^{-}, \mathrm{BO}_{3}{ }^{3-}, \mathrm{ClO}_{3}{ }^{-}, \mathrm{Br}^{-}, \mathrm{IO}_{4}{ }^{-}, \\
\mathrm{SCN}^{-}, \mathrm{S}_{2} \mathrm{O}_{8}{ }^{2-}, \mathrm{CO}_{3}{ }^{2-}, \mathrm{PO}_{4}{ }^{3-}, \mathrm{I}^{-}, \mathrm{CH}_{3} \mathrm{COO}^{-}, \\
\mathrm{IO}_{3}{ }^{2}, \mathrm{Na}^{+}, \mathrm{K}^{+}, \mathrm{Ba}^{2+}, \mathrm{Fe}^{2+}, \mathrm{Cr}^{3+}, \mathrm{Mn}^{2+}, \mathrm{Hg}^{2+}, \\
\mathrm{Cu}^{2+}, \mathrm{Al}^{3+}, \mathrm{Ag}^{+}, \mathrm{Zn}^{2+}\end{array}$ & 1000 \\
\hline $\mathrm{Mg}^{2+}, \mathrm{Mo}^{6+}, \mathrm{V}^{5+}, \mathrm{Rh}^{3+}, \mathrm{S}_{2} \mathrm{O}_{3}{ }^{2-}, \mathrm{Pd}^{2+}, \mathrm{Ru}^{3+}$ & 800 \\
\hline $\mathrm{Ni}^{2+}, \mathrm{Se}^{4+}$ & 500 \\
\hline $\mathrm{Pb}^{2+}, \mathrm{Co}^{2+}$ & 200 \\
\hline $\mathrm{Cd}^{2+}$ & 100 \\
\hline $\mathrm{N}_{2} \mathrm{H}_{4}$ & 50 \\
\hline
\end{tabular}

method efficiency, and recoveries of the added phenylhydrazine by this analysis method were satisfactory (Table 2).

3.7. Interferences. In this stage, the influence of contaminant species presented in various samples for the determination of phenylhydrazine, $0.1 \mu \mathrm{mol} \mathrm{L}{ }^{-1}$, was investigated. The tolerance limit was defined as the concentration of added ions causing a relative error less than $3 \%$ (Table 3 ). The results show that the developed method is very selective.

\section{Conclusions}

The proposed FI spectrophotometric method has proven to be simple and sensitive for phenylhydrazine determination. The linearity of the calibration graph is in the useful concentration range for quantitation of phenylhydrazine in human serum and water samples. The method developed simple, economic, rapid, providing a good sample frequency of $40 \mathrm{~h}^{-1}$ and is especially suitable for routine analysis.

\section{Acknowledgment}

The authors express their gratitude to the Center of Excellency in Science of Islamic Azad University-Majlesi Branch for support of this work.

\section{References}

[1] J. Berger, "Phenylhydrazine haematotoxicity," Journal of Applied Biomedicine, vol. 5, no. 3, pp. 125-130, 2007.

[2] M. Evgen'ev, N. Nikolaeva, I. Evgen'eva, and I. Zheltukhin, "Spectrophotometric determination of phenylhydrazine in sewage," Journal of Analytical Chemistry, vol. 47, p. 1247, 1992.

[3] T. Hasan, "Resin bead detection and spectrophotometric determination of phenylhydrazine using inorganic reagents," Analytical Letters, vol. 21, no. 4, pp. 633-640, 1988. 
[4] J. P. Rawat and P. Bhattacharjee, "Spectrophotometric determination of phenylhydrazine with ammonium molybdate," Mikrochimica Acta, vol. 66, no. 5-6, pp. 619-624, 1976.

[5] A. R. Zarei and M. A. Zarei, "Spectrophotometric determination of trace amounts of phenylhydrazine in water and biological samples after preconcentration by the cloud point extraction method," Asian Journal of Chemistry, vol. 21, no. 2, pp. 1042-1050, 2009.

[6] N. Singh, M. Mehrotra, K. Rastogi, and T. N. Srivastava, "Separation and determination of phenylhydrazine-N-dithiocarbamates of ruthenium(III), rhodium(III) and palladium(II) from other group VIII metals using thin-layer chromatography and visible spectrophotometry," The Analyst, vol. 110, no. 1, pp. 71-73, 1985.

[7] A. Afkhami and A. R. Zarei, "Simultaneous spectrophotometric determination of hydrazine and phenylhydrazine based on their condensation reactions with different aromatic aldehydes in micellar media using H-point standard addition method," Talanta, vol. 62, no. 3, pp. 559-565, 2004.

[8] M. A. Karimi, M. Mazloum Ardakani, H. Abdollahi, and F. Banifatemeh, "Application of H-point standard addition method and partial least squares to the simultaneous kineticpotentiometric determination of hydrazine and phenylhydrazine," Analytical Sciences, vol. 24, no. 2, pp. 261-266, 2008.

[9] V. Miti, S. D. Nikoli, and V. Stankov-Jovanovi, “The development of a new inhibition kinetic spectrophotometric method for the determination of phenylhydrazine," Journal of the Serbian Chemical Society, vol. 70, no. 7, pp. 987-993, 2005.

[10] M. A. Karimi, M. A. Taher, R. B. Ardakani, and S. Abdollahzadeh, "Application of principle component regression and partial least square to the simultaneous kinetic-spectrophotometric determination of ternary mixture of hydrazine, phenylhydrazine and acetylhydrazine," Asian Journal of Chemistry, vol. 20, no. 3, pp. 2169-2179, 2008.

[11] M. Arab Chamjangali, G. Bagherian, and S. Ameri, "A new induction period based reaction rate method for determination trace amounts of phenylhydrazine in water samples," Journal of Hazardous Materials, vol. 166, no. 2-3, pp. 701-705, 2009.

[12] A. Afkhami and A. A. Assl, "Sensitive spectrophotometric determination of trace quantities of phenylhydrazine," Microchemical Journal, vol. 69, no. 1, pp. 51-57, 2001.

[13] Z.-S. Yang, W.-L. Wu, X. Chen, and Y.-C. Liu, "An amperometric horseradish peroxidase inhibition biosensor for the determination of phenylhydrazine," Analytical Sciences, vol. 24, no. 7, pp. 895-899, 2008.

[14] M. R. Akhgar, M. Salari, H. Zamani, A. Changizi, and H. Hosseini-Mahdiabad, "Electrocatalytic and simultaneous determination of phenylhydrazine and hydrazine using carbon paste electrode modified with carbon nanotubes and ferrocenedicarboxylic acid," International Journal of Electrochemical Science, vol. 5, no. 6, pp. 782-796, 2010.

[15] M. A. Khalilzadeh and H. Karimi-Maleh, "Sensitive and selective determination of phenylhydrazine in the presence of hydrazine at a ferrocene monocarboxylic acid modified carbon nanotube paste electrode," Analytical Letters, vol. 43, no. 1, pp. 186-196, 2010.

[16] N. Rastakhiz, A. Kariminik, V. Soltani-Nejad, and S. Roodsaz, "Simultaneous determination of phenylhydrazine, hydrazine and sulfite using a modified carbon nanotube paste electrode," International Journal of Electrochemical Science, vol. 5, no. 9, pp. 1203-1212, 2010.
[17] A. A. Ensafi, M. A. Chamjangali, and H. Rahimi Mansour, "Catalytic spectrophotometric determination of ruthenium by flow injection method," Talanta, vol. 55, no. 4, pp. 715-720, 2001. 

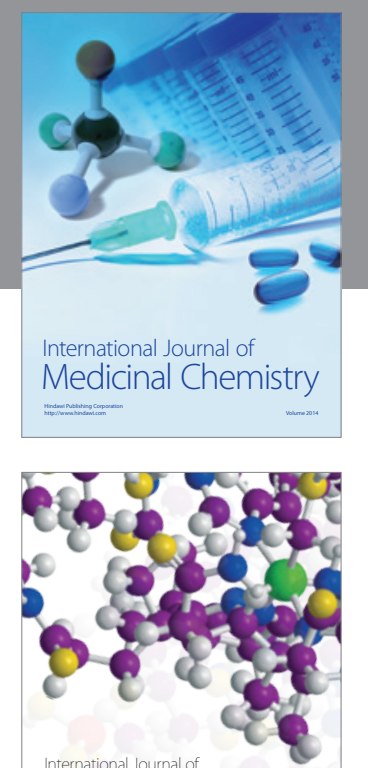

\section{Carbohydrate} Chemistry

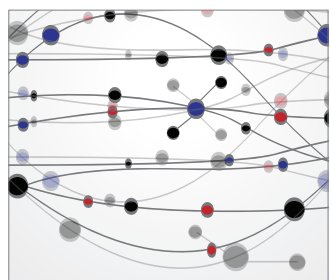

The Scientific World Journal
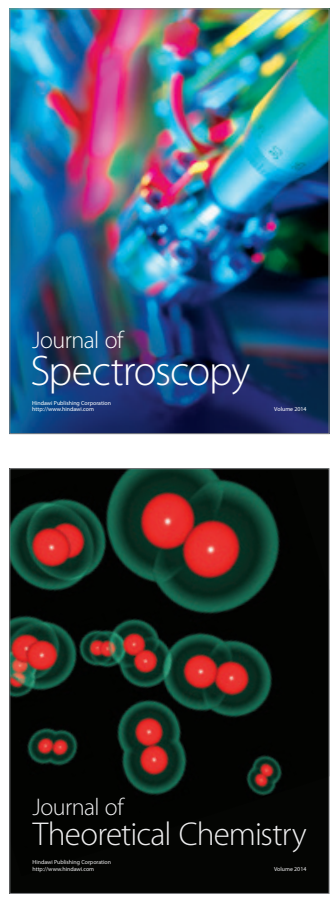
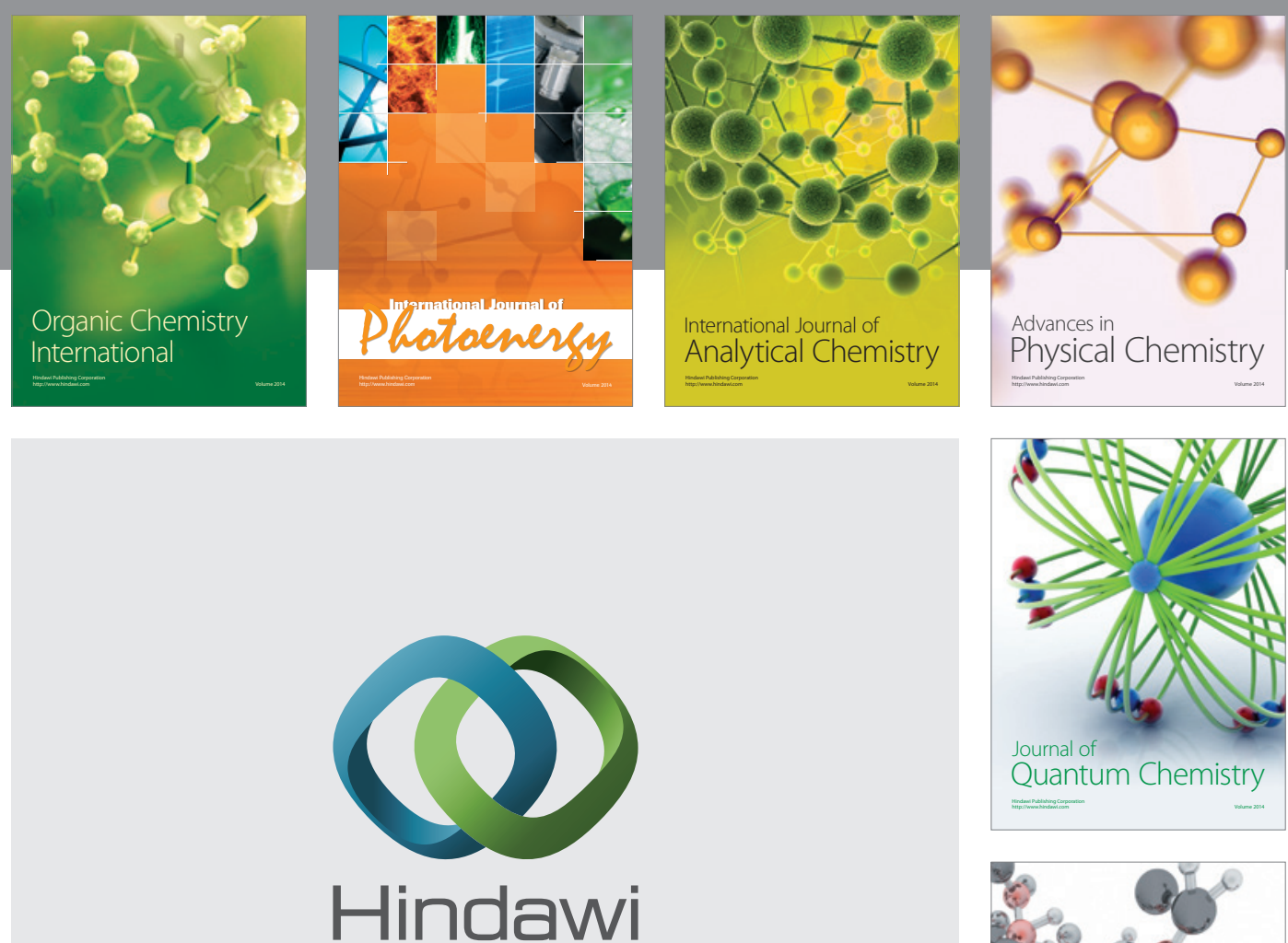

Submit your manuscripts at

http://www.hindawi.com

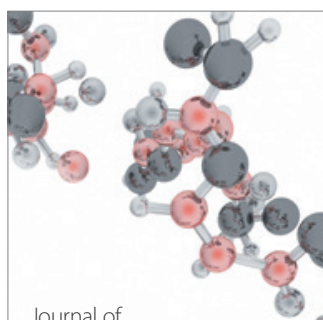

Analytical Methods

in Chemistry

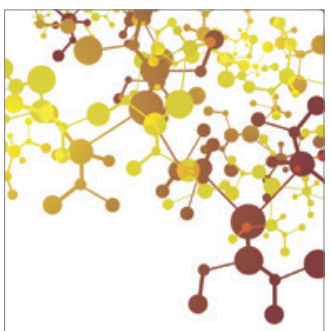

Journal of

Applied Chemistry

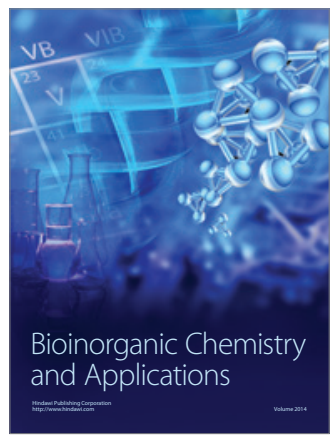

Inorganic Chemistry
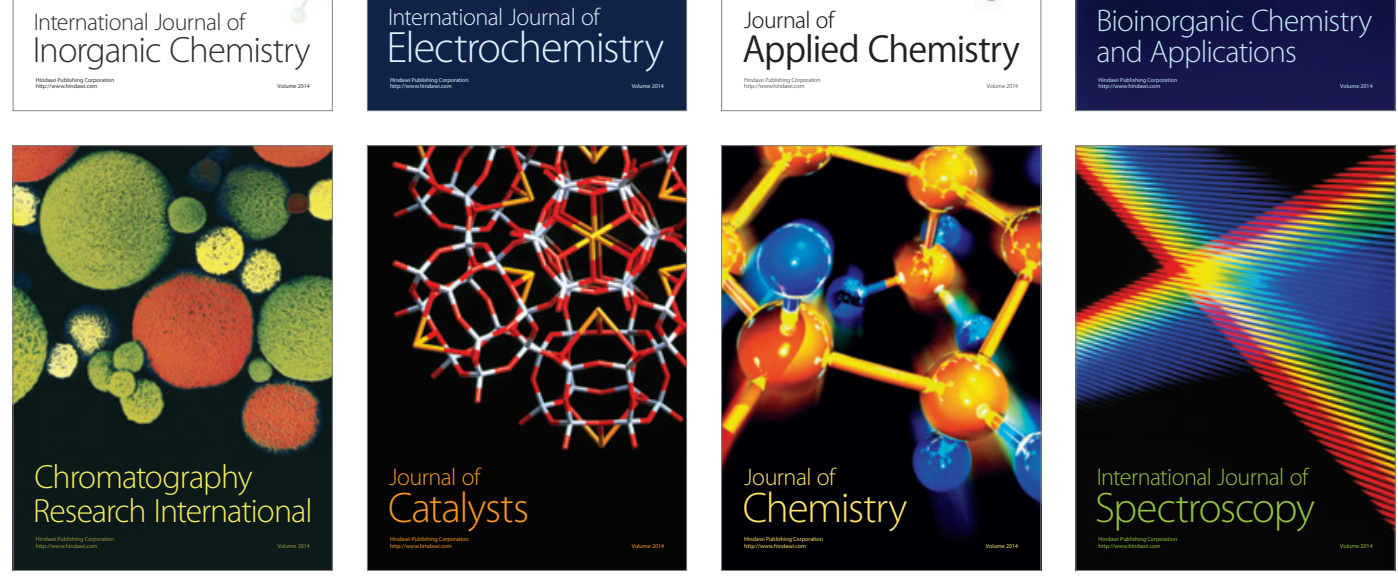